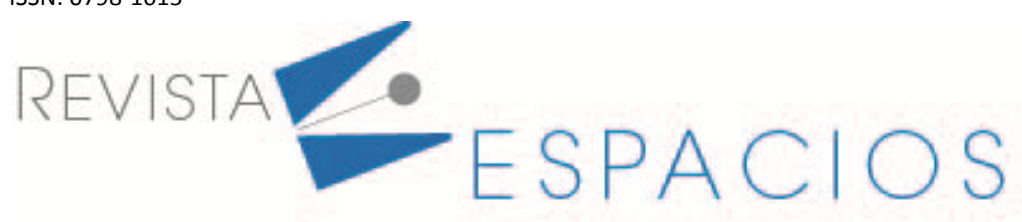

\title{
Foreign language preparedness for vocational communication of students in flight educational institutions
}

\author{
Preparación de idiomas extranjeros para la comunicación vocacional de estudiantes en \\ instituciones educativas de vuelo.
}

\author{
SAVCHENKO, Nataliia Serhiivna ${ }^{1}$ \\ NECHEPORUK, Yana Serhiivna ${ }^{2}$
}

\begin{abstract}
Ukrainian aviation is one of the most promising industries that can and should represent us in the global world as an active subject of economic and social cooperation. Meanwhile, it is obvious that the industry needs significant and urgent transformations, in particular related to the implementation of global standards and coordinated rules of communication between functional participants in air transport: pilots and air traffic controllers. The peculiarity of the tasks of up-to-date higher education is the effective process of specialists' training. It has to meet the needs of society in specialists who have a high level of readiness for vocational communication in foreign language, professional culture, ability to a quick respond to production tasks, to notice and to raise problems, successfully solve them in a new way, improving existing rules and technologies. The condition of successful professional activity is a deep professional knowledge, the desire for its constant enrichment, independent and critical thinking, and ability to create their own projects for implementation in practice.

Key words: foreign language training, aviation specialists, preparedness, vocational communication.
\end{abstract}

\section{Resumen}

La aviación ucraniana es una de las industrias más prometedoras que puede y debe representarnos en el mundo global como un sujeto activo de cooperación económica y social. Mientras tanto, es obvio que la industria necesita transformaciones importantes y urgentes, en particular relacionadas con la implementación de estándares globales y reglas coordinadas de comunicación entre participantes funcionales en el transporte aéreo: pilotos y controladores de tráfico aéreo. La peculiaridad de las tareas de la educación superior actualizada es el proceso eficaz de formación de especialistas. Tiene que satisfacer las necesidades de la sociedad en especialistas que tengan un alto nivel de preparación para la comunicación vocacional en lengua extranjera, cultura profesional, capacidad para una rápida respuesta a las tareas de producción, para advertir y plantear problemas, resolverlos con éxito de una nueva manera. , mejorando las reglas y tecnologías existentes. La condición de una actividad profesional exitosa es un conocimiento profesional profundo, el deseo de su enriquecimiento constante, pensamiento independiente y crítico, y capacidad para crear sus propios proyectos para su implementación en la práctica.

Palabras clave: formación en lenguas extranjeras, especialistas en aviación, preparación, comunicación profesional.

\footnotetext{
${ }^{1}$ Volodymyr Vynnychenko Central Ukrainian State Pedagogical University. Email: yananecheporuk83@gmail.com

${ }^{2}$ Volodymyr Vynnychenko Central Ukrainian State Pedagogical University. Email: nataliy-savchenko@yandex.ua
} 


\section{Introduction}

Nowadays, the process of Ukrainian higher education transformation has only just begun, witnessing a number of positive changes and modifications. Thus, the "Foreign language" discipline has a communicatively and professionally oriented nature in the flight educational institutions. It develops the formation of students' communicative and language competencies, which allow them to use effectively the language in professional activities. Teaching a foreign language to specialists in non-language educational institutions should be professionally oriented. A paramount component of such training is the process of transition from the study of language as a subject to its practical application for specific purposes (Korchahyn \& Safyn, 2016).

Analysis of foreign and domestic researchers' works shows that the problem of clarifying the meaning of the concepts of "preparedness", "communication", "vocational communication", "preparedness for vocational foreign language communication" becomes complex, ambiguous and debatable. There is also no consensus on the types of preparedness. Based on the study of different approaches, which try to clarifying the essence of the "preparedness definition and its concept, it is stated that it's a psychophysiological, emotional, motivational state that allows a person (specialist) to perform his professional tasks successfully and effectively. In the case of successful formation of readiness, the specialist is able to reveal it in both long-term and situational conditions (Kovtun, 2010; Krivchykova, 2003).

We define preparedness for vocational foreign language communication as a state of guaranteed ability to conduct successful English-language radio exchange in non-standard and standardized circumstances on the basis of international norms of aviation communication, which provide a dynamic combination of knowledge, practical skills, ways of thinking, information in the conditions of individual interaction of the pilot and the dispatcher.

\section{Methodology}

The concept of research is based on present-day requirements for vocational foreign language training of flight cadets. It influences the content and specifics, defines the goals, methods, principles of improving its optimization. The educational services' market is actively developing, which stimulates the institutions to revise their approach to professional training. It is essential to propose new teaching methods and modes, to create new organizational forms of pedagogical activity (Kobrina et al., 2018).

The effectiveness of vocational foreign language training of flight cadets is ensured by:

methodological concept provides the interaction and relationship of fundamental scientific approaches of solving the education problems, which were used in the study, in particular: professionally oriented, communicative, competence based on field qualifications framework and recognition of international certificates of foreign language proficiency. There are several of them: personally orientated approach, approach of systematic educational activity, linguistic adaptive approach etc.;

concept of an active individual role in a process of learning, which causes a change in the essence of the educational process, its content, forms and methods. This concept gives the opportunity to reveal her/his inner potential, capability for independent formation and taking a decisions, choose the educational direction and content of educational material, that is the most appropriate for future professional activities, find and fill the gaps in knowledge, change the static role and standard functions of a teacher;

methodological and technological concept of the study, which provides for the development and experimental testing of pedagogical conditions and adaptive educational system of training the flight cadets for vocational foreign language usage in future professional activity. 
Practical work on the issue of ensuring the preparedness of cadets for foreign professional language communication motivated us to use the following research methods:

- theoretical - analysis of philosophical, psychological and pedagogical literature to clarify the essence of concepts, justification of the structure, criteria and indicators of preparedness of cadets for foreign professional communication. Classification, systematization and generalization of theoretical regulations concerning the problem of preparedness of cadets for foreign professional communication in order to define the main areas and directions of research; modeling, which made it possible to develop a model of preparedness of cadets for foreign professional communication (Savchenko et al., 2018);

- empirical - observation of the educational process and the study of pedagogical experience to clarify the difficulties in forming the preparedness of cadets for foreign professional communication; study of regulatory documentation, which made it possible to explore the specifics of aviators' professional activities; conversations (questionnaires) - to characterize the flight cadets' attitude towards the outlined problem; conducting diagnostic procedures - questionnaires, surveys, testing;

- statistical - mathematical processing of empirical data to prove the reliability of the results of a pedagogical experiment.

Issues of theory and methods of teaching a foreign language in vocational schools were studied by H.V. Astashova, M.B. Kazachkova, O.B. Parakhina, S.K. Folomkina. The connection between learning a foreign language in a non-language educational institution and the professional training of specialists is reflected in the works of A.P. Bieliaievoi, L.M. Kalashnikovoi, H.M. Lesokhinoi, E.Ye. Oliinyka, H.P. Savchenko, L.M. Chaurskoi and others. L.I. Bohatikova, H.V. Yelizarova, M.H. Yevdokymova, T.V. Kuchma, I.L. Pluzhnyk, I.V. Samoiliukevych, O.V. Syromiasov, N.D. Soloviova, L.V. Shylak have devoted their works to the oral professional communication teaching of foreign language in a non - language educational institution. Despite the achievements in the sphere of vocational foreign language learning, we can still notice the necessity of improving the quality of foreign language knowledge in teaching practice, especially in the context of real professional communication in aviation.

In order to improve the preparation of flight cadets of domestic aviation educational institutes for professional foreign language communication it was suggested to apply the following pedagogical conditions in the educational process:

1) introduction of adapted forms and methods of interactive classroom learning in the cycle of disciplines of professional and practical training;

2) intensification of professional interaction by creating a professional English-language functional environment by means of extracurricular activities of cadet pilots and cadet dispatchers;

3) motivation for independent acquire the necessary knowledge and skills in professional English through the use of experience of existing aviation specialists in the form of tutoring. Therefore, we conducted a pedagogical experiment in several domestic flight educational institutions in order to confirm or to refute the hypothesis of the study and test the format of existing and suggested type of cadets' training.

Analysis of theoretical resources served as a basis for identifying the following components of cadets' preparedness for vocational foreign language communication (Moskalenko, 2019):

- operational and activity (criterion: procedural; indicators: pronunciation, use of grammatical structures, vocabulary, fluency of speech, listening, communication according to the $4^{\text {th }}$ level of the ICAO scale). The practical study of indicator' level of the operational component was carried out on the basis of practical test (that was 
developed according to the $4^{\text {th }}$ level of ICAO requirements) which helped to characterize the following key vocational language skills of cadets: pronunciation; use of grammatical structures (volume and correctness of answers); vocabulary; fluency of speech; listening; communication (ICAO, 2010).

- stimulating-motivational (criterion: motivational; indicators: personal interest in a chosen profession, desire for effectiveness in vocational training, desire for professional self-improvement and self-discipline). The study of the motivational component is based on a special method that was created by V.G. Katashev. The motive, as a rule, plays the role of the real reason of interested attitude to the process of studying and to the future professional activity. It can be asserted that the most active student in vocational training will be that one who realizes the necessity of specific knowledge necessary for future professional activities. The future specialist recognizes his profession as the only or main source of his/her material and spiritual needs satisfaction. The interpretation of this method takes into account 2-3-4 levels of motivation, because the 1st level is not typical for young people who have chosen this specialty. So in the description of motivation levels the first, the second and the third levels, are identified with the second, the third and the fourth levels of the general method. Studies based on these techniques have shown that in the process of professional advancement of the cadet it is important to measure periodically his motivation and adjust, if necessary, his/her professional self-awareness in the future career.

- creative activity (criterion: creative; indicators: creative thinking, curiosity, originality, imagination, intuition, emotionality, sense of humor, creative attitude to the profession). Indicators of the creative-activity component were determined using the "Creativity" test (according to N. Vyshnyakova). The testing revealed the level of creative tendencies of the individual and built a psychological and creative profile that reflects the creative component of the image. That allows us to diagnose the level of creative tendencies of the cadets. This technique covers such important indicators of creativity for aviation as: creative thinking, curiosity, originality, imagination, intuition, emotionality, sense of humor and creative attitude to the profession. Comparing the two images of creativity "I am real" and "I am ideal" makes it possible to determine the creative reserve and creative potential of the individual. Cadets were asked to assess their own personal qualities by answering the questions of the test.

The study was conducted during 2018-2020 academic years, on the basis of foreign language departments of Flight Academy of the National Aviation University, Kremenchug Flight College of the National Aviation University and Kharkiv University of the Air Force named after I.M Kozheduba. There were 698 people who took part in the observational stage of the experiment: 588 cadets of Flight Academy of the National Aviation University, 38 cadets of Kremenchug Flight College of the National Aviation University and 72 cadets of Kharkiv University of the Air Force named after I.M Kozheduba.

Within a frame of pedagogical experiment, we also used the method of anonymous survey of flight cadets. As a result, it turned out that, despite the large number of scientific papers on improving the process of learning a foreign language for professional use, the vast majority of cadets answered that they did not experience fundamental changes in teaching methods of professional disciplines. To the question: "Do you feel the introduction of the latest methods of professional English learning in your flight school?" $70 \%$ of respondents answered "No"; $20 \%$ of respondents said that they sometimes notice innovations in the process of professional English teaching and only $10 \%$ of all respondents clearly answered "Yes". $73 \%$ of respondents would like to take part in classes in the form of: simulation of professional situations, discussion and analysis of specific situations, practical classes with a professional role execution and specific vocabulary usage, research work. The cadets' answers survey showed that teachers with different periods of work experience rarely show interest in aviation specialties. Students of flight schools also expressed some wishes concerning the process of vocational foreign language studying among them are analysis of aviation accidents and catastrophes in English; presentations on 
aviation topics, watching movies related to aviation and others. During the English classes, cadets are interested, in addition to the traditional (translation, reading the text, giving the answers to the questions) also in nonstandard methods of language learning (presentations, quizzes, watching movies on aviation topics, with mandatory discussions, simulation the process of standard and non-standard flight procedures).

While planning and organizing the experiment, we focused the attention on the fact that the future aviation specialist should understand that now it is important not only to gain knowledge and practice, but also to have diverse skills and abilities. Future air traffic controllers and pilots should be aware that they need to be highly erudite people, able to adapt to any working conditions both within their country and abroad. Currently, the domestic aviation space is increasingly narrowing and for successful professional activity, vocational English (aviation) remains one of the priority disciplines of flight schools. We relied on the responsibility of cadets and saw in them future aviation professionals who have the aim of developing and improvement and accumulate a clear aviation professional orientation in themselves (Sovgira et al., 2019).

\section{Results}

The effectiveness of the particular pedagogical conditions and developed methods were tested by conducting control diagnostic sections before and after the formative experiment. That allowed to trace the dynamics of formation the professional competencies of professional activities in the process of English vocational language learning.

During the process of pedagogical experiment: a) actively used technical means (audio, video materials, mini radio stations, other technical means which simulate the pilot and controller's activity); b) part of the classes were conducted in specialized simulators and with special cockpit devices; c) cadets were given the opportunity to get acquainted with the authentic operation manual of modern aircraft (Saab, Boeing); d) there were held the interactions with teachers of profile disciplines during the preparation of project works on the topic "GPS Application" and reports "Radio Navigation Systems"; e) cadets were provided with individual consultations by teachers of English and other specialized disciplines while working on projects and reports (ICAO.a, 2010; ICAO, 2007). Digital competence has become a focus that has received special interest since it was conceived as one of the basic skills that any citizen should develop at the end of the compulsory educational stage. Developing it has become an indispensable requirement to function effectively in the new information and knowledge society, and also as an indispensable skill that is needed for lifelong learning (Rodríguez-Garcia et al., 2019).

It should also be noted that, firstly, the experiment provides an opportunity to distinguish artificially the desired phenomenon from other pedagogical phenomena in educational process of aviation educational institutions; secondly, the experiment makes it possible to manage the process of preparedness for vocational foreign language communication; thirdly, the pedagogical experiment is characterized by complexity, as it involves the use of different methods of research and the simulation of special situations; fourthly, the author of the study personally participates in the experiment, which creates the background to consider it included in this process, so it is possible to correlate the objective results of the formation of cadets' preparedness for communication in foreign language with a subjective assessment of this process.

The organization of the study involved comparing the results of experimental groups at the beginning and at the end of the experiment. In the experimental groups the educational process was carried out on the basis of suggested pedagogical conditions, and cadets of the control groups the process of studying took place traditionally, in accordance with the curricula.

The objectivity of the obtained data is ensured by: firstly, the equivalence of the control and experimental groups; secondly, involving in the pedagogical experiment several domestic flight educational institutions; 
thirdly, using different methods of diagnostics of the level of adaptation (self-assessment, use of diagnostic research methods, expert assessment, interview, observation, questionnaire, testing, survey of cadets, methods of mathematical statistics).

The results of the pedagogical experiment can be considered truthful if the experimental and control groups are statistically homogeneous in a number of indicators. The experimental group consisted of 249 people: 199 cadets of Flight Academy of the National Aviation University, 25 cadets of Kremenchug Flight College of the National Aviation University, 25 cadets of Kharkiv University of the Air Force named after I.M Kozheduba. The control group was formed in the amount of 246 people: 196 cadets of Flight Academy of the National Aviation University, 15 cadets of the Kremenchug Flight College of the National Aviation University, 35 cadets of Kharkiv University of the Air Force named after I.M. Kozheduba.

There was a checking of readiness and sections of knowledge in each group at the end of the experiment. It was used the same initial methods and tests to diagnose the level of knowledge, skills, motivation and creativity of future aviation specialists, but taken into consideration the guidelines we have previously developed and introduced.

According to the results of re-testing the operational and activity component of the formation of cadets' readiness for professional foreign language communication, it is concluded that in the experimental group the percentage proportions are preserved, and this testifies to the stability of the educational process. The cadets have a tendency to reduce the number of incorrect answers and increase the number of cadets who received higher scores, which is an indicator of positive dynamics

Figure 1

The results of testing the operational and activity component of cadet's preparedness for vocational foreign language communication BEFORE and AFTER the experiment
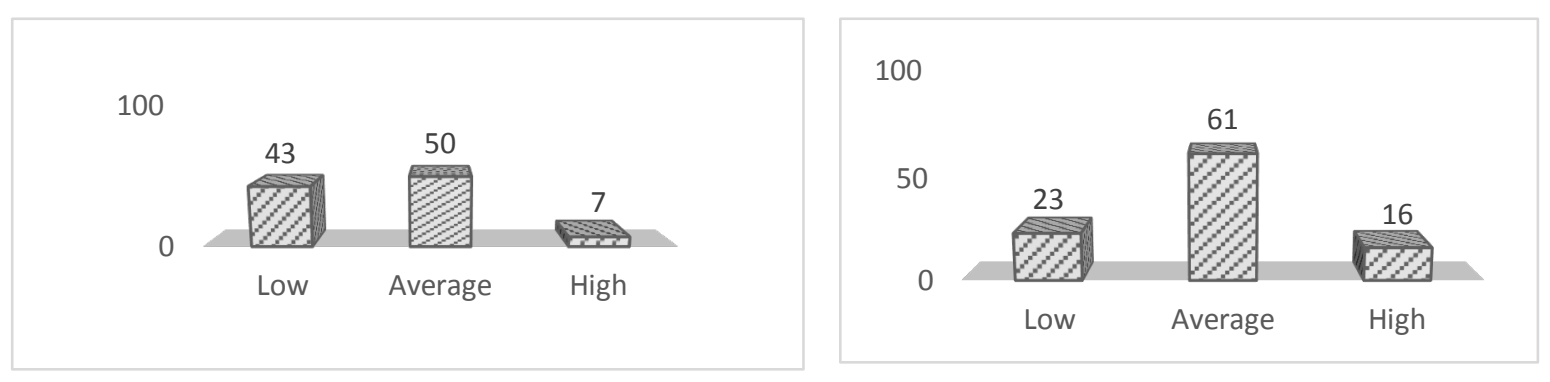

The analysis of the obtained results gives grounds to draw the following conclusions: the positive dynamics in the operational indicators is recorded by all criteria in each of the tasks: a) the speech of cadets has become more literate; $b$ ) the volume of expressions and phrasal verbs has increased, the vocabulary has increased; c) the fluency of speech has accelerated, and the duration of pauses has decreased; d) the informative richness of monologue, dialogic statements and remarks is strengthened; d) cadets have acquired radio communication skills, following the procedure of transmission and reception of messages in accordance with ICAO requirements. 
Figure 2

The results of testing the stimulus-motivational component of the cadet's preparedness for vocational foreign language communication BEFORE and AFTER the experiment
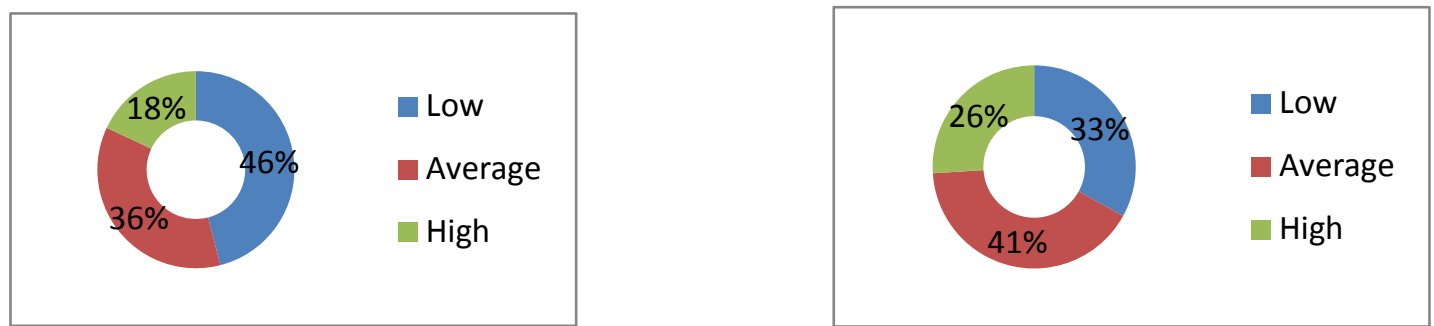

According to the results of conducted survey during the formative experiment, it was stated that the number of cadets in experimental group has increased to average 41\% (97 people) and high $26 \%$ (95 people) level of creativity. The number of cadets with a low level of creative potential decreased to $33 \%$ (57 people).

Figure 3

Generalized image of creative-activity component indicators of the cadet's preparedness for vocational foreign language communication BEFORE and AFTER the experiment

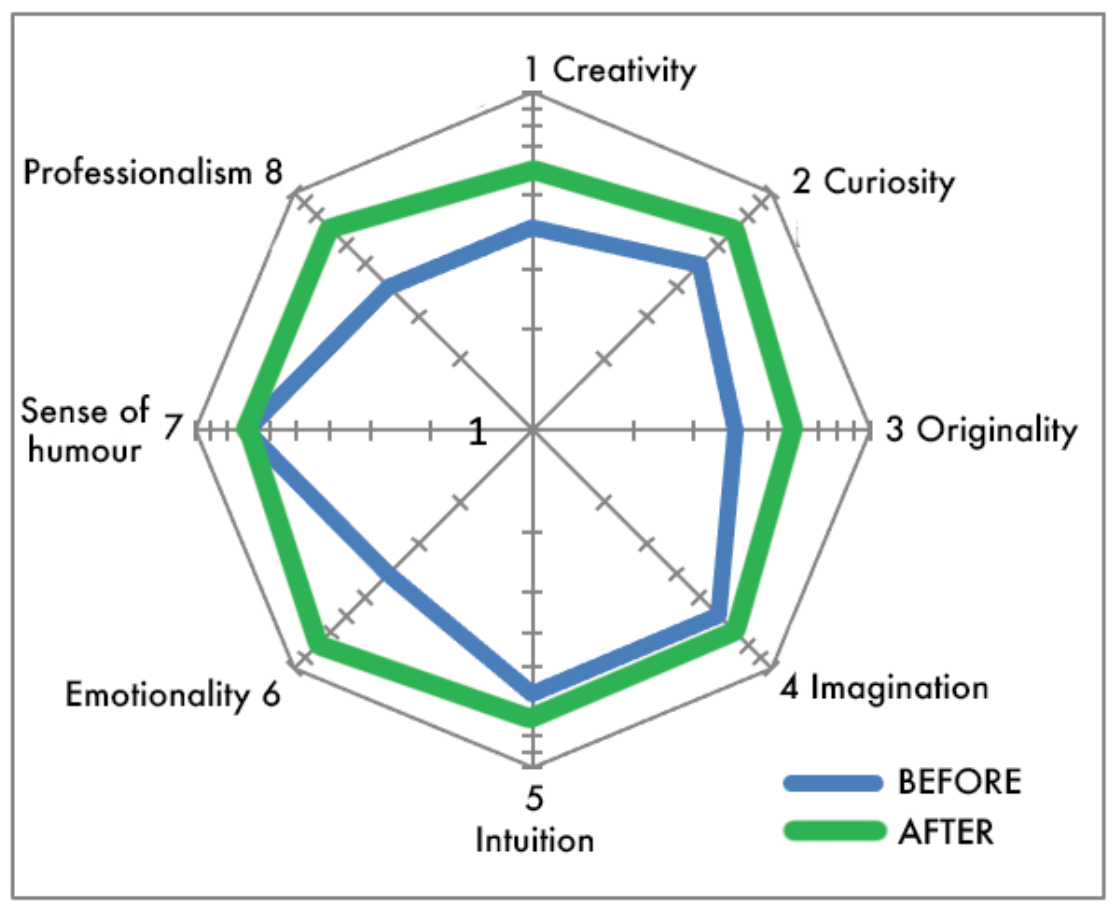

The indicators of the diagrams show a positive and dynamic growth of cadets' creative potential in experimental group. Despite the technical component of the disciplines, future aviation professionals demonstrate quite serious attitude towards the creative and activity component. The use of games in education is one of the most effective means for grabbing the attention of learners and emphasizes the educational theories.

To confirm the reliability of indicators of operational-activity, motivational-stimulating and creative-activity components of cadet's preparedness for vocational foreign language communication, Pearson's $\chi 2$-criterion is used. Its aim is to check empirical and theoretical or other empirical distribution of one trait. This criterion is used to compare the empirical distribution of a feature with the theoretical distribution or for a comparative analysis of two empirical distributions of the same feature. 
Here is the general formula for calculating the $\chi 2$-Pearson test:

$$
\chi_{e m p}^{2}=\sum_{i} \frac{\left(\mathbf{n}_{\mathbf{i}}-\mathbf{n}_{\mathbf{i}}^{\prime}\right)^{2}}{\mathbf{n}_{\mathbf{i}}^{\prime}}
$$

The sample sizes must be at least 50 and the equality of frequency sums observed:

$$
\sum_{i} n_{i}=\sum_{i} n_{i}^{\prime}
$$

$n_{i}$ - the sample size of category according to the state of defined property, in our case - the group at the beginning of the experiment; $n_{i}^{\prime}{ }^{-}$is the sample size of according to the state of the defined property (at the end of the experiment).

Thus, the analysis of the pedagogical experiment results confirmed the effectiveness of suggested pedagogical conditions.

\section{Conclusion}

There are the main conditions for the effectiveness of our cadets' training format: introduction of adapted forms and methods of interactive classroom learning in the cycle of disciplines of professional and practical training; intensification of vocational interaction by creating a professional English-language functional environment by means of mutual extracurricular activities of cadet pilots and cadet ATC controllers; motivation to independently acquire the necessary knowledge and skills in professional English using the experience of current aviation specialists as a form of tutoring in flight educational institutions.

The effectiveness of the process of preparedness for vocational foreign language communication was also influenced by:

- multilevel nature of foreign language learning, which involves the formation of communicative competencies in accordance with the ICAO language standards;

- communicative orientation of foreign language teaching, which allows students to form competencies on which the success and effectiveness of professional communication depends;

- organization of foreign language training on the basis of professionally oriented materials;

- integration of educational pedagogical technologies (with active use of technical means (audio, video materials, mini radio stations, other technical means that simulate the work of the pilot and dispatcher)) and the use of specialized simulators and special cockpit devices;

- opportunity to get acquainted with authentic operation manuals of modern aircraft (Saab, Boeing) (ICAO.b, 2010);

- getting the individual consultations by teachers of English and other specialized disciplines while working on projects and reports which allows to implement the principle of individual foreign language approach.

The experimental study confirmed the effectiveness of suggested pedagogical conditions.

\section{References}

International Civil Aviation Organization (2010) Manual on the Implementation of ICAO Language Proficiency Requirements Doc 9835 
International Civil Aviation Organization (2010), Resolution A38-8 Proficiency in the English language used for radiotelephony communications, available at: https://www.icao.int/safety/lpr/Documents/A38.8.pdf

International Civil Aviation Organization (2007), Manual of Radiotelephony Doc 9432, $4^{\text {th }}$ Edition available at:https://www.ealts.com/documents/ICAO\%20Doc\%209432\%20Manual\%20of\%20Radiotelephony\%20(4t h\%20ed.\%202007).pdf

International Civil Aviation Organization Manual on the Approval of Training Organizations Doc 9841, $3^{\text {rd }}$. Available at: https://www.yumpu.com/en/document/read/45896063/manual-on-the-approval-oftraining-organizations-doc-9841-an-456-

Kobrina L. M.; Vilkova A. V.; Tishchenko Y.Y.; Maslennikov E.E.; Smorodinskaia I.A. (2018). Usage of simulation method «Educational Corporation» in professional schools, Vol. 39 (Number 25), Page 31. Retrieved from: https://www.revistaespacios.com/a18v39n25/a18v39n25p31.pdf https://www.revistaespacios.com/a18v39n25/a18v39n25p31.pdf

Korchahyn E.A.; Safyn R.S. (2016), “Competence-based approach and traditional view of higher education" Vyssheye obrazovaniye $v$ Rossii [Online] Vol. 11(206), available at: https://cyberleninka.ru/article/n/kompetentnostnyy-podhod-i-traditsionnoe-predstavlenie-o-vysshemobrazovanii

Kovtun, O.V. (2010), "Influence of information and communication technologies of modern aircraft on the organization of language education of future aviation operators" Naukovyi visnyk Donbasu [Online], vol. 1 (9), available at: http://nvd.luguniv.edu.ua/archiv/NN9/index.htm

Krivchykova, H.F. (2003), "Experimental verification of the effectiveness of interactive learning of written speech", Visnyk Kyivskoho natsionalnoho linhvistychnoho universytetu [Online], vol.6

Moskalenko, O.I. (2019), "Components, criteria, indicators and levels of motivation of future foreign aviation specialists to professional communication", Naukovyi chasopys Natsionalnoho pedahohichnoho universytetu imeni M.P. Drahomanova [Online], vol.67, available at: http://enpuir.npu.edu.ua/handle/123456789/27064

Rodriguez-Garcia, A.M.; Aznar D.I.; Caceres R.P.; Gomez G.G. (2019). “Digital competence in higher education: analysis of the impact of scientific production indexed in Scopus database", Vol. 40 (Number 21), Page 14. Retrieved from: https://www.revistaespacios.com/a19v40n21/19402114.html

Savchenko Nataliia, Kotelianets Natalka, Kotelianets Yuliia, Dubinka Mikola, Nikitina Olena, (2018), "Modeling the methodological system of studying as a way of technological competence formation", "International Journal of Civil Engineering and Technology" (IJCIET) Volume 9, Issue 11, available online at: http://www.iaeme.com/ijciet/issues.asp?JType=IJCIET\&VType=9\&IType=11

Sovgira Svitlana, Bida Olena, Leshchenko Hennadii, Zakharova Oksana, Chernyshenko Iryna (2019), "Development of leadershippotential in the system of higher education: civil aviation students" "InternationalJournal of Innovation, Creativity and Change», Vol. 8, Issue 11, United Kingdom, Australia, available at: https://www.ijicc.net/index.php/volume-8-2019/140-vol-8-iss-11

Esta obra está bajo una Licencia Creative Commons Attribución-NoCommercial 4.0 International

(cc) BY-NC 